\title{
BMJ Open Japanese newspaper advertisements for dietary supplements before and after COVID-19: a content analysis
}

\author{
Tsuyoshi Okuhara (D) , ${ }^{1}$ Rie Yokota (D) , ${ }^{1}$ Ritsuko Shirabe, ${ }^{1}$ Reina lye, ${ }^{1}$ \\ Hiroko Okada, ${ }^{1}$ Takahiro Kiuchi, ${ }^{1}$ Tsuyoshi Chiba, ${ }^{2}$ Rie Akamatsu ${ }^{3}$
}

To cite: Okuhara T, Yokota R, Shirabe R, et al. Japanese newspaper advertisements for dietary supplements before and after COVID-19: a content analysis. BMJ Open 2021;11:e050898. doi:10.1136/ bmjopen-2021-050898

- Prepublication history for this paper are available online. To view these files, please visit the journal online (http://dx.doi org/10.1136/bmjopen-2021050898).

Received 05 March 2021 Accepted 08 November 202

Check for updates

(c) Author(s) (or their employer(s)) 2021. Re-use permitted under CC BY-NC. No commercial re-use. See rights and permissions. Published by BMJ.

${ }^{1}$ Department of Health Communication, The University of Tokyo, Bunkyo-ku, Tokyo, Japan

${ }^{2}$ Department of Food Function and Labeling, National Institute of Health and Nutrition, National Institutes of Biomedical Innovation, Health and Nutrition, Shinjuku-ku, Tokyo, Japan ${ }^{3}$ Natural Science Division, Ochanomizu University, Bunkyoku, Tokyo, Japan

Correspondence to Dr Tsuyoshi Okuhara; okuhara-ctr@umin.ac.jp

\section{ABSTRACT}

Objectives Public health institutions have alerted consumers about advertising for dietary supplements with false claims of preventing or treating COVID-19. We quantitatively and qualitatively examined newspaper advertisements for dietary supplements before and after the COVID-19 spread.

Design Content analysis.

Participants We analysed advertisements for dietary supplements in two major Japanese newspapers in February-July 2019 and February-July 2020. Our analysis covered 2167 advertisements.

Results The number of advertisements for dietary supplements that claimed to be effective in infection prevention $(p=0.009)$ and improving joint $(p=0.002)$ and digestive functions $(p=0.002)$ significantly increased after the spread of COVID-19 compared with before. Dietary supplements that claimed to be effective in preventing infection were advertised in combination with recommendations for gargling and handwashing. Such terms as 'defence' and 'prevent' were used to promote the preventive effect.

Conclusions False and misleading claims in advertising for dietary supplements may result in consumer harm, such as overdosing and failure to take preventive behaviour. While the pandemic continues, there will be an increasing need for disseminating accessible information about the appropriate use of dietary supplements, consumer education and warnings to manufacturers.

\section{INTRODUCTION}

During the COVID-19 pandemic, voluntary restraint from leaving the home has restricted people's access to food and led to changes in the food environment, such as encouraging individuals to purchase food items through home delivery and mail order. The pandemic has changed people's dietary behaviour. Consumption of fruit and vegetables decreased $^{2}$ and of confections increased ${ }^{3}$; however, some people chose healthier diets. ${ }^{4}$ In Japan, $30.2 \%$ of men and $38.2 \%$ of women used dietary supplements before the spread of COVID- $19^{5}$; the market for such supplements in 2019 was $¥ 8623$ billion. ${ }^{6}$ Further, per household consumption expenditure

\section{Strengths and limitations of this study}

- We hypothesised that newspaper advertisements for dietary supplements that claimed to have an infection prevention effect have increased since the spread of COVID-19.

- We examined the functions and ingredients claimed in advertisements for dietary supplements that have increased since the spread of COVID-19.

- We investigated the content and changes in the number of advertisements that claimed to have an infection prevention effect.

- We discuss the issues related to advertising dietary supplements during the pandemic and improving consumer communication and education.

- This study has limited generalisability because the sources and context related only to Japan.

on dietary supplements (ie, products taken in addition to the normal diet to promote health ${ }^{7}$ ) increased for seven consecutive months from February 2020, when the spread of COVID-19 began in the country; in August 2020 , it showed a $51.7 \%$ increase over the previous year. $^{8}$

Several systematic reviews and meta-analyses have, however, reported that most dietary supplements are ineffective in preventing or treating disease ${ }^{9-11}$; moreover, serious safety issues and drug supplement interactions have been reported. ${ }^{12-14}$ Additionally, safety issues arise from overdosing dietary supplements: a U-shaped relationship between supplement dosing and mortality has been observed for several dietary supplements; this finding indicates that overdosing dietary supplements can bring substantial toxicity. ${ }^{15-17}$

Nevertheless, dietary supplements are widely advertised-often with unsubstantiated claims of benefit and with little mention of potential hazards. ${ }^{16}{ }^{17}$ Advertising and labels of dietary supplements are often misleading, and consumers may believe that dietary supplements prevent and treat disease without causing any harm. ${ }^{18-20}$ Studies have reported 
that many consumers believe that advertising claims for dietary supplements are generally true. ${ }^{21-23}$ Research has found that advertisements for dietary supplements may lead consumers to take poor decisions and actions regarding health: the advertisements focus on increasing consumer motivation to purchase without addressing the scarcity of scientific evidence for the products. ${ }^{24}{ }^{25}$ Consequently, advertising for dietary supplements may have negative effects on consumers, for example, overconsuming such supplements with the risk of side effects and reducing appropriate lifestyle behaviour. ${ }^{25}$ However, research and public health practice have paid little attention to regulating and improving communication between manufacturers and consumers. ${ }^{26}$

During an unprecedented state of emergency, such as the COVID-19 pandemic, the possibility increases for manufacturers to take advantage of people's anxiety and promote their products with inappropriate advertisements. The US Food and Drug Administration, ${ }^{27}$ Japan's Consumer Affairs Agency, ${ }^{28}$ Health Canada, ${ }^{29}$ Singapore's Health Science Authority ${ }^{30}$ and Australia's Therapeutic Goods Administration ${ }^{31}$ have all expressed concern about the potential negative effects of inappropriate use of dietary supplements during the pandemic; they have issued warnings to consumers about advertising dietary supplements with false claims about preventing or treating COVID-19. However, to our knowledge, no study has investigated the content of and changes to dietary supplement advertising during the pandemic. Accordingly, the present research quantitatively and qualitatively examined the following: study aim 1, functions and ingredients claimed in Japanese newspaper advertisements for dietary supplements that have increased since the spread of COVID-19; study aim 2, changes in the number of advertisements that claimed to have an infection prevention effect as well as the content of advertisements that promoted such effects against COVID-19. We hypothesised that newspaper advertisements claiming an infection prevention effect have increased since the spread of COVID-19. We discuss the issues related to advertising dietary supplements during the pandemic as well as improved consumer communication and education regarding those issues.

\section{MATERIALS AND METHODS \\ Materials}

Newspaper readership remains strong in Japan. In 2019, about $70 \%$ of Japanese subscribed to a newspaper. ${ }^{32}$ In 2020, the annual circulation of morning newspapers in Japan was 8099445 for the Yomiuri Shimbun and 5579398 for the Asahi Shimbun; they accounted for around $70 \%$ of the total circulation of Japan's five national newspapers. ${ }^{33}$ This study examined the morning editions of those two largest national newspapers for February-July 2019 (before the spread of COVID-19) and February-July 2020 (after COVID-19 had begun to spread). The newspapers analysed were in Japanese and carried advertisements in that language.

\section{Coding items, included and excluded content}

In Japan, the content of dietary supplement advertisements is regulated under the Health Promotion Act and the Act against Unjustifiable Premiums and Misleading Representations; Japanese dietary supplement advertisements are not allowed to advocate any effectiveness in treating or preventing disease. ${ }^{34}$ Because of that regulation, it was hard to imagine that advertisements in Japan's two largest national newspapers would advocate prevention or treatment of COVID-19. Therefore, we were interested in identifying advertisements that indicated an effect on COVID-19. In light of Japanese regulation of dietary supplement advertisements, we adopted the following coding procedure.

Among the authors, RY, RS and RI were responsible for reading all the pages of the newspapers in question. RY, RS and RI inductively coded all advertisements for dietary supplements that appeared in the newspapers. They entered into Microsoft Excel such information as the following: date and volume (ie, number of newspaper columns) of the advertisements; functions and active ingredients the advertisements claimed; and phrases used in the advertisements that were considered to promote a preventive effect against COVID-19. The first author (TO) read all the newspaper pages and checked for omissions and errors in the coding results of RY, RS and RI. Then, TO, RY, RS and RI discussed the claimed functions in the coded advertisements. In line with the study aims, TO, RY, RS and RI included for analysis advertisements that claimed functions that were expected to increase owing to the spread of COVID-19 (eg, infection prevention, stress and physical and cognitive functions); they excluded advertisements they believed unrelated to increased advertising because of the pandemic (eg, bad breath, hay fever and ultraviolet protection). Finally, TO, RY, RS and RI reviewed and discussed the coded phrases they considered related to a preventive effect against COVID-19; they decided which phrases to include for analysis.

\section{Statistical analysis}

The analysed newspapers had 12 columns, so we converted the volume of advertisements into values based on the number of columns (eg, 12 columns $=1,6$ columns $=0.5,3$ columns $=0.25$ ). We tabulated the number and volume of advertisements into three separate units for each month: $1 \mathrm{~s}-10$ th; 11 th-20th and 21st to the end of the month. We compared the medians of the volume of advertisements between 2019 and 2020 using the Mann-Whitney U test. In the statistical tests, we set a $\mathrm{p}<0.05$ as significant. We undertook statistical analyses using IBM SPSS Statistics for Windows, V.21.0 (IBM).

\section{Patient and public involvement}

No patients were involved in this study. 
Table 1 Claimed functions and number of advertisements

\begin{tabular}{|c|c|c|c|c|}
\hline Function & Advertisement claims & No (\%) & Volume (\%) & $\begin{array}{l}\text { Median of volume } \\
(\text { IQR })^{\star}\end{array}$ \\
\hline Not specified & $\begin{array}{l}\text { Did not specify a particular } \\
\text { function }\end{array}$ & $829(38.3)$ & 343.25 (33.5) & $9.58(7.20-11.98)$ \\
\hline Recovery from fatigue & Effect on recovery from fatigue & $51(2.4)$ & $35.18(3.4)$ & $0.33(0.00-1.46)$ \\
\hline Infection prevention & $\begin{array}{l}\text { Effect on infection prevention, } \\
\text { enhancing immunity and } \\
\text { resistance }\end{array}$ & $42(1.9)$ & $23.40(2.3)$ & $0.00(0.00-0.66)$ \\
\hline Stress & Stress reduction & $12(0.6)$ & $12.00(1.2)$ & $0.00(0.00-1.00)$ \\
\hline Sleep & Effect on improving sleep & $94(4.3)$ & $41.85(4.1)$ & $0.99(0.66-1.82)$ \\
\hline Joint function & $\begin{array}{l}\text { Improvement for leg joints and } \\
\text { general joint function }\end{array}$ & $281(13.0)$ & $166.48(16.2)$ & $4.18(3.30-5.82)$ \\
\hline Muscle strength & $\begin{array}{l}\text { Maintenance and improvement } \\
\text { of muscle strength }\end{array}$ & $42(1.9)$ & $33.29(3.2)$ & $1.00(0.02-1.46)$ \\
\hline Visual function & Improved visual function & $163(7.5)$ & $61.38(6.0)$ & $1.50(1.03-2.28)$ \\
\hline Cognitive function & $\begin{array}{l}\text { Improved memory and } \\
\text { cognitive function }\end{array}$ & $55(2.5)$ & $27.50(2.7)$ & $0.37(0.19-1.00)$ \\
\hline Digestive function & Improved digestive function & $178(8.2)$ & $71.82(7.0)$ & $1.99(1.02-2.65)$ \\
\hline Fat reduction & $\begin{array}{l}\text { Effect on reduced visceral fat, } \\
\text { triglyceride, cholesterol, body } \\
\text { fat, and body weight }\end{array}$ & $182(8.4)$ & $93.63(9.1)$ & $2.82(1.21-3.66)$ \\
\hline Blood vessels & $\begin{array}{l}\text { Improved blood pressure and } \\
\text { prevention of blood clots }\end{array}$ & $98(4.5)$ & $56.54(5.5)$ & $1.25(0.33-2.41)$ \\
\hline Blood sugar & Improved blood sugar level & $109(5.0)$ & $41.07(4.0)$ & $0.92(0.35-1.89)$ \\
\hline
\end{tabular}

*The median values were based on 10-day aggregated results.

\section{RESULTS}

\section{Claimed functions and number of advertisements}

For our analysis, we included advertisements for dietary supplements that claimed to be effective for the following: recovery from fatigue; infection prevention; reducing stress; improving sleep; enhancing joint function; improving muscle strength; enhancing bone density; improving visual function; enhancing cognitive function; improving digestive function; reducing fat; and improving the blood vessels and blood sugar. We also included advertisements that did not specify a function. We excluded from our analysis advertisements for dietary supplements that claimed to improve the following: frequent urination; uric acid levels; liver function; bad breath and body odour; hay fever; ultraviolet protection; menopausal disorders in women; and sexual function in men. We did not find any advertisements that specifically referred to COVID-19 using terms such as coronavirus, or that explicitly advocated prevention or treatment of COVID-19. This is due to the aforementioned legal restrictions in Japan.

For the analysed advertisements, table 1 presents the claimed functions, number and percentage, volume and percentage, and medians for volume. The number and volume of advertisements included in the analysis were 2167 and 1024.8, respectively. The largest volume of advertisements $(33.5 \%)$ did not specify any functions; they were followed by ones that claimed improved joint function $(16.2 \%)$, fat reduction $(9.1 \%)$ and improved digestive function $(7.0 \%)$. The total numbers of manufacturers and products were 166 and 342, respectively, in 2019; they were 161 and 327 in 2020.

\section{Comparison before and after the infection}

Regarding study aim 1, table 2 shows the results of comparing the number of advertisements before (2019) and after (2020) the spread of COVID-19. The total number and volume and the median of the volume of advertisements that claimed to be effective in infection prevention were 5, 3.30 and 0.00 , respectively, before the spread of the infection; those figures increased to $37,20.10$ and 0.33 after the infection began spreading; the difference was significant $(p=0.009)$. Those numbers for advertisements that claimed improved joint function were $126,64.75$ and 3.58 , respectively, before the spread of the infection; they increased to 155, 101.73 and 5.66 after the infection began spreading; the difference was significant $(p=0.002)$. Those figures for advertisements 
Table 2 Comparison before and after the spread of infection

Before (2019)

\begin{tabular}{|c|c|c|c|c|c|c|c|}
\hline \multirow[b]{2}{*}{ Function } & & & \multirow[b]{2}{*}{$P$ value } \\
\hline & No (\%) & Volume (\%) & $\begin{array}{l}\text { Median of volume } \\
(\text { IQR)* }\end{array}$ & No (\%) & Volume (\%) & $\begin{array}{l}\text { Median of volume } \\
\text { (IQR)* }\end{array}$ & \\
\hline Not specified & $469(43.0)$ & 196.59 (38.7) & $10.24(8.23-14.07)$ & $360(33.4)$ & $154.44(29.9)$ & $9.43(5.91-10.42)$ & 0.790 \\
\hline $\begin{array}{l}\text { Infection } \\
\text { prevention }\end{array}$ & $5(0.5)$ & $3.30(0.6)$ & $0.00(0.00-0.08)$ & $37(3.4)$ & $20.10(3.9)$ & $0.33(0.00-2.20)$ & 0.009 \\
\hline Sleep & $46(4.2)$ & $20.90(4.1)$ & $0.7(0.64-1.96)$ & $48(4.5)$ & $20.95(4.1)$ & $0.99(0.66-1.80)$ & 0.767 \\
\hline Joint function & $126(11.6)$ & $64.75(12.7)$ & $3.58(2.39-5.01)$ & $155(14.4)$ & 101.73 (19.7) & 5.66 (3.99-8.03) & 0.002 \\
\hline Muscle strength & $22(2.0)$ & $20.49(4.0)$ & $1.00(0.33-2.00)$ & $20(1.9)$ & $12.80(2.5)$ & $0.50(0.00-1.08)$ & 0.104 \\
\hline Bone density & $14(1.3)$ & $7.91(1.6)$ & $0.085(0.00-0.56)$ & $17(1.6)$ & $9.50(1.8)$ & $0.25(0.00-1.00)$ & 0.650 \\
\hline Fat reduction & 108 (9.9) & $59.61(11.7)$ & $3.20(1.99-4.22)$ & $74(6.9)$ & $34.02(6.6)$ & $1.62(0.99-3.26)$ & 0.003 \\
\hline Blood vessels & $60(5.5)$ & $28.27(5.6)$ & $1.25(0.33-2.58)$ & $38(3.5)$ & $28.27(5.5)$ & $1.25(0.33-2.58)$ & 1.000 \\
\hline Blood sugar & $51(4.7)$ & $21.49(4.2)$ & $0.87(0.33-2.12)$ & $58(5.4)$ & $19.58(3.8)$ & $0.92(0.39-1.83)$ & 0.719 \\
\hline Total & 1089 & 508.06 & $1.00(0.33-2.33)$ & $1078(100)$ & $516.74(100)$ & $1.08(0.33-2.66)$ & 0.310 \\
\hline
\end{tabular}

*The median values were based on 10-day aggregated results.

that claimed improved digestive function were 60, 25.88 and 1.37 , respectively, before the spread of the infection; they increased to $118,45.94$ and 2.56 after the infection began spreading; the difference was significant $(p=0.002)$. Those numbers for advertisements that claimed to be effective in recovery from fatigue were $20,14.89$ and 0.29 , respectively, before the spread of the infection; they increased to 31, 20.29 and 0.83 after the spread of the infection; however, the difference was not statistically significant $(p=0.161)$. By contrast, those figures for advertisements that claimed enhanced fat control were 108, 59.61 and 3.20, respectively, before the spread of infection; they decreased to 74, 34.02 and 1.62 after the spread of the infection; the difference was significant $(\mathrm{p}=0.003)$.

\section{Active ingredients}

With regard to study aim 1, table 3 presents the active ingredients that were cited in the advertisements that significantly increased during COVID-19 in 2020. The ingredients claimed to prevent infection were such items as lactic acid bacteria, lactoferrin and propolis; for improved joint function, they were such items as type II collagen, glucosamine and chondroitin; for enhanced digestive function, they were such items as lactic acid bacteria, inulin and chlorogenic acid.

\section{Time series changes}

With respect to study aim 2, figure 1 shows the time series of changes in the number of advertisements that claimed to be effective in preventing infection in 2020;

Table 3 Active ingredients in advertisement claims that increased during the spread of COVID-19 in 2020

\begin{tabular}{ll}
\hline Function & Ingredient (no*) \\
\hline Infection prevention & $\begin{array}{l}\text { Lactic acid bacteria, for example, Lactobacillus pentosus strain S-PT84, Lactobacillus delbrueckii subspp. } \\
\text { bulgaricus OLL1073R-1 (17), lactoferrin (7), propolis (7), royal jelly (4), methylglyoxal (3), taurine (3), amino } \\
\text { acids, for example, cystine, theanine (3) }\end{array}$ \\
Joint function & $\begin{array}{l}\text { Type II collagen (89), glucosamine (86), chondroitin (83), proteoglycan (61), quercetin (55), anserine (44), } \\
\text { vitamin D (40), hyaluronic acid (31), imidazole dipeptide (26), methylsulfonylmethane (4), BCAA (valine, leucine, } \\
\text { isoleucine) (1) }\end{array}$ \\
Digestive function & $\begin{array}{l}\text { Lactic acid bacteria, for example, Lactobacillus bifidus, Lactobacillus brevis, Lactobacillus gasseri (93), inulin } \\
\text { (27), chlorogenic acid (14), dietary fibre (11), lactoferrin (9) }\end{array}$
\end{tabular}

${ }^{*}$ A single product often contained multiple active ingredients; thus, the total numbers for each ingredient in table 3 do not match those in table 2. 


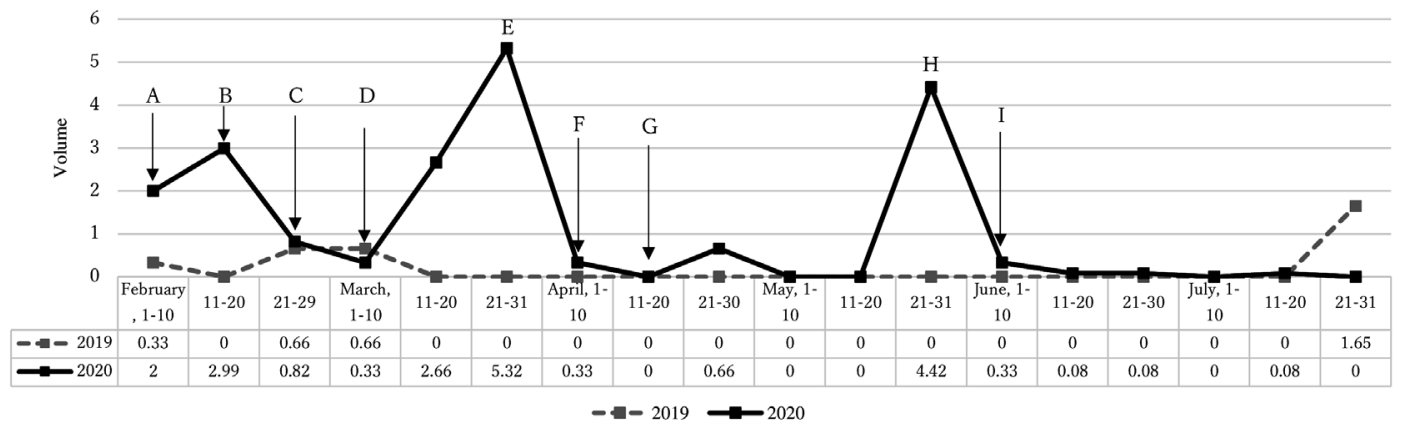
A. February 3: A cruise ship with a cluster of COVID-19 infections entered port in Yokohama.
B. February 13: The first infected person died in Japan.
C. February 27: The government requested temporary closure of elementary and junior high schools nationwide.
D. March 10: The Consumer Affairs Agency requested improvements in advertisements (first time).
E. March 27: The Consumer Affairs Agency requested improvements in advertisements (second time).
F. April 7: The government declared a state of emergency in seven prefectures.
G. April 16: The state of emergency was extended to the whole country.
H. May 25: The state of emergency was lifted nationwide.
I. June 5: The Consumer Affairs Agency requested improvements in advertisements (third time).

Figure 1 Time series of changes in the number of advertisements that claimed infection prevention.

it also presents the major events related to COVID-19 in Japan. Advertisements claiming an effect in preventing infection increased in 11-20 February, 11-31 March and 21-31 May; they decreased in 1 April-20 May and 1 June 1-31 July.

\section{Phrases that promoted preventive effect against COVID-19 infection}

Regarding study aim 2, table 4 presents the phrases used in advertisements that were considered related to a preventive effect against COVID-19. The products were advertised in combination with infection prevention measures, such as gargling and handwashing. Such keywords as 'defence' and 'prevent' were used to imply an effect on preventing infection.

\section{DISCUSSION}

The number of advertisements that claimed to be effective in preventing infection, improving joint function and enhancing digestive function increased in FebruaryJuly 2020 compared with February-July 2019. Manufacturers may have regarded the spread of COVID-19 as a commercial opportunity and invested in advertisements that claimed to be effective in infection prevention. The market for dietary supplements, such as lactic acid bacteria and propolis, grew in Japan in 2020 as people became increasingly interested in preventing infection. ${ }^{6}$

Manufacturers may have predicted that reduced physical activity owing to restraint from leaving the home ${ }^{24}$ would increase the need for dietary supplements for enhanced joint function. The main target group of dietary supplements for improved joint function is older people. ${ }^{35}$ In Japan, the main readers of newspapers are also elderly individuals. ${ }^{32}$ Manufacturers may have invested in newspaper advertisements for dietary supplements for enhanced joint function because the products' target population coincided with the age group of newspaper readers. Advertisements for dietary supplements for digestive function mainly claimed that they contained lactic acid bacteria, as shown in table 3. In Japan, the mass media have made very frequent reports about intestinal flora since 2015, and lactic acid bacteria are widely believed to enhance immunity. ${ }^{36}$ Accordingly, manufacturers may have recognised the spread of COVID-19 as a commercial opportunity and invested in advertising dietary supplements containing lactic acid bacteria for improved digestive function. Dietary supplement advertisements for recovery from fatigue increased in 2020 compared with 2019, although the difference was not significant. One reason for the statistically insignificant difference could be the smaller number of advertisements related to recovery from fatigue (20 in 2019, 31 in 2020); thus, the number of advertisements was unable to attain statistical significance. It is conceivable that manufacturers believed the spread of COVID-19 to be a commercial opportunity, and they invested in advertisements claiming an effect for recovery from fatigue as a means of personal protection from infection. By contrast, the number of advertisements claiming fat reduction decreased in 2020 compared with 2019. To invest efficiently with respect to increased market demand, manufacturers may have decided to be selective and focus their resources.

According to Japan's National Institute of Health and Nutrition, ${ }^{37}$ among the active ingredients in table 3, only glucosamine $\mathrm{e}^{38} 39$ and chondroitin ${ }^{40}$ for improving joint function, and lactic acid bacteria ${ }^{41}$ and dietary fibre, ${ }^{42}$ for improving digestive function, are effective. The institute based that conclusion on the findings of meta-analysis studies. Research has shown that lactic acid bacteria have preventive effects on common cold symptoms, such as respiratory tract infections. ${ }^{44} 45$ There is insufficient 
Table 4 Phrases that indicated preventive effects against COVID-19

\begin{tabular}{|c|c|c|}
\hline & Product & Phrase \\
\hline \multirow[t]{6}{*}{$\begin{array}{l}\text { Product } \\
\text { advertisement }\end{array}$} & Yoghurt drink & $\begin{array}{l}\text { Let's get started. } \\
1 \text {, gargling; } 2 \text {, handwashing; three name and a picture of the product }\end{array}$ \\
\hline & Propolis supplement & $\begin{array}{l}\text { The power of 'defence' and 'prevention' produced by honeybees } \\
\text { Power of Baccaris-derived propolis }\end{array}$ \\
\hline & Propolis supplement & $\begin{array}{l}\text { At this time of concern about health, propolis for 'defence' } \\
\text { (depicting a crowd of people) }\end{array}$ \\
\hline & Lactoferrin yoghurt drink & $\begin{array}{l}\text { Strengthen your body from within } \\
\text { Lactoferrin to take good care of your health. } \\
\text { (depicting a man, a woman, and a child holding shields) }\end{array}$ \\
\hline & Amino acid supplement & $\begin{array}{l}\text { Supports 'vitality,' which protects you! } \\
\text { Gargling and hand washing with amino acids. }\end{array}$ \\
\hline & Drink & Protect your body yourself! \\
\hline $\begin{array}{l}\text { Enlightenment } \\
\text { advertisement }\end{array}$ & Bifidobacterium & $\begin{array}{l}\text { Immunity increases } \\
\text { Taking bifidobacteria enhances immunity, so it's effective in preventing influenza and } \\
\text { suppressing the onset of pollinosis. }\end{array}$ \\
\hline
\end{tabular}

evidence to judge whether they have preventive effects against COVID-19. ${ }^{46}$

As evident in table 4, however, advertisements used phrases that indicated preventive effects against COVID19. For example, one advertisement for a lactic acid bacteria supplement claimed, 'This time when you need a mask, 'defence' is important.' One advertisement for an amino acid supplement claimed, 'Supports 'vitality,' which protects you! Gargling and handwashing with amino acids.' Such claims are structure-function claims: they describe the intended benefit of the supplement with respect to bodily structure or function. ${ }^{20}$ Research has determined that structure-function claims mislead consumers into believing that dietary supplements can prevent or treat disease. ${ }^{18} 19$ This study found that some advertisements employed images to imply a preventive effect against COVID-19. For example, one advertisement for a propolis supplement displayed an image of a crowd of people and made the claim, 'At this time of concern about health, propolis to the defence.'

In such ways, manufacturers promoted their products by skillfully using the Japanese characteristic of highcontext communication. ${ }^{47}$ In Japan, the Health Promotion Law and the Act against Unjustifiable Premiums and Misleading Representations regulate the representations of advertisements for dietary supplements. ${ }^{34}$ Those laws prohibit misleading and unsubstantiated claims that products may prevent or treat disease. ${ }^{34}$ The advertisements listed in table 4 were designed to circumvent such legal restrictions and appeal to consumers about a preventive effect against COVID-19. Although nutritional interventions for disease prevention and treatment have gained considerable scientific support, social distancing and hygiene precautions are the best ways to reduce the risk of COVID-19 infection. ${ }^{48}$ Despite the lack of scientific evidence for preventive effects, consumers may take those 
dietary supplements, hoping to achieve the desired effect because of the compelling wording of the advertisers. If consumers overdosed on such dietary supplements or failed to follow standard preventive behaviour or health behaviour owing to laxity when taking the supplements, the advertising would likely cause actual harm.

The first peak in the volume of advertisements claiming an effect in preventing infection occurred from 11 February 2020 to 20 February 2020. Just previously, on 3 February, a cruise ship with a cluster of COVID-19 infections arrived at the port of Yokohama; the first death of an infected person in Japan was reported on 13 February. A little before the second peak from 11 March to 31 March, the Japanese government announced on 27 February that all elementary and junior high schools would be temporarily closed. In response to these influential events, which raised concern about COVID-19, manufacturers may have quickly placed advertisements that emphasised infection prevention, thereby generating the two peaks. In March, Japan's Consumer Affairs Agency twice requested that manufacturers improve Internet advertisements for dietary supplements making false claims about preventing COVID-19. ${ }^{49}$ If the advertising of dietary supplement violates the Health Promotion Act and Act against Unjustifiable Premiums and Misleading Representations, the Consumer Affairs Agency conducts on-site inspections of the companies involved and requests improvements in the wording of their advertisements. ${ }^{34}$ If a company violates such a request, it will be punished by imprisonment or a fine. ${ }^{34}$ Following those requests in March, advertisements decreased from 1 April to 20 May. Although those requests addressed internet advertising, manufacturers may have also refrained from placing newspaper advertisements. The third peak was from 21 May to 31 May. Following the third request on 5 June by the Consumer Affairs Agency to improve advertising, ${ }^{49}$ almost no advertisements about infection prevention appeared. Thus, the surveillance of Internet advertising by the Consumer Affairs Agency may have also affected the placement of newspaper advertisements. Lack of adequate surveillance and inadequate regulation may pose a public harm from supplement use, ranging from financial loss to serious adverse health consequences. ${ }^{18} 1926$ Surveillance and requests for improvements by public institutions with respect to advertising for dietary supplements will become increasingly important toward decreasing inappropriate advertising during the pandemic. ${ }^{50}$

In Japan, the Consumer Affairs Agency and the National Institute of Health and Nutrition have posted information for consumers on their Web sites regarding the appropriate use of dietary supplements for COVID-19. ${ }^{37} 51$ In addition to this effort, it would be helpful for such public institutions as the Consumer Affairs Agency to disseminate information that is more accessible to consumers. For example, public institutions could place newspaper advertisements about the appropriate use of dietary supplements during the pandemic. Further, through social media, health professionals could spread suitable information, such as about healthy eating and critical reviews of advertising dietary supplements. ${ }^{52}$ Health professionals could also work with journalists to circulate information through the mass media. Such information could help consumers in not confusing dietary supplements with drugs ${ }^{53}$ : if dietary supplements promote biological activity, as their advertisements indicate, they should be considered active drugs. ${ }^{18}$ Conversely, if dietary supplements are claimed to be safe because they lack or minimise biological activity, their ability to produce physiological changes should be questioned and their distribution as health-promoting products curtailed. ${ }^{18}$

Consumer education about the distinction between dietary supplements and drugs is especially important in the psychological and informational chaos of COVID19. Consumer education is needed to clarify that most dietary supplements lack any positive effects ${ }^{9-11}$ but do have serious safety issues. ${ }^{12-14}$ Repeated efforts to inform and educate consumers will be needed to help them deal with deceptive advertising and use dietary supplements appropriately during the pandemic. It is beyond doubt that manufacturers should bear the burden for providing accurate, accessible information about the potential limitations and risks involved with dietary supplements. ${ }^{20}$ Advertisements for dietary supplements should not make claims that are unsupported by scientific evidence, but they should include appropriate information about side effects; that is the case with advertisements for therapeutic drugs. ${ }^{18} 1926$ Researchers need to study the impact of advertising inappropriate dietary supplements on consumer perception and behaviour. Many studies have shown that unhealthy food and beverage marketing increase dietary intake and influence dietary preferences in children, adolescents, and adults. ${ }^{55-59}$ However, research on the effect of advertising for dietary supplements is scarce.

This study has several limitations. It is unknown whether our results apply to advertisements in newspapers other than those we analysed or to magazine, television and internet advertisements in Japan and overseas. In addition to the spread of COVID-19, related events, and surveillance of advertising by public institutions, other factors (such as market trends, corporate publicity, advertising strategies and manufacturer competition) may have influenced the placing of newspaper advertisements. The coding we applied may have reflected our own bias. An association between newspaper advertisements for dietary supplements and COVID-19 did not explicitly emerge in this study: advertisements could not directly mention COVID-19 owing to restrictions on advertising dietary supplements in Japan. However, with respect to advertising regulations and high-context communication in Japan, it is important to focus on the impact on consumers of indirect suggestions contained in advertising. In light of these limitations, our results should be interpreted with caution. But to our knowledge, this is the first study to focus on dietary supplement advertising with regard to changes in dietary 
environment and behaviour during COVID-19; it offers important implications.

\section{CONCLUSIONS}

This study observed an increase in advertising of dietary supplements that claimed to be effective in infection prevention and improving joint function and digestive function during COVID-19. Our results indicate that manufacturers may have regarded the pandemic as a commercial opportunity: they boosted their investment in advertising for dietary supplements amid the increased market demand through COVID-19. However, most of the active ingredients in the advertised dietary supplements lacked sufficient scientific evidence. This study also found advertisements that claimed the supplements provided a preventive effect against infection despite an absence of adequate scientific evidence. During the pandemic, such advertisements may encourage consumers to overdose on dietary supplements and fail to adopt appropriate health and preventive behaviour. Advertisements claiming to prevent infection evidently increased and decreased in response to events related to the pandemic and warnings to manufacturers by Japan's Consumer Affairs Agency. That underlines the importance of surveillance by public institutions. While the pandemic persists, there will be increasing need for alerts to consumers and warnings to manufacturers by public institutions regarding advertising for dietary supplements; there will likewise be such a need for consumer education. It is also important that public institutions and health professionals should disseminate accessible information on the appropriate use of dietary supplements. In this time of an unprecedented pandemic, there should be no possibility of advertisements for dietary supplements, which are supposed to promote health, that actually cause harm.

Acknowledgements We thank Edanz (https://jp.edanz.com/ac) for editing a draft of this manuscript.

Contributors TO conceived and designed the study. TO, RY, RS and RI contributed to data collection, data analysis and interpretation. TO wrote the manuscript. RY, $\mathrm{RS}, \mathrm{RI}, \mathrm{HO}, \mathrm{TC}, \mathrm{TK}$ and RA contributed to the critical revision and editing of the manuscript. RA acquired funding and supervised the study. T0 was a guarantor.

Funding This work was supported by a Health, Labour and Welfare Policy Research Grants (Special Research) (subject number 20CA2040).

Competing interests None declared.

Patient consent for publication Not applicable.

Ethics approval The study was granted exemption from ethical approval by the ethical review committee at the Graduate School of Medicine, The University of Tokyo.

Provenance and peer review Not commissioned; externally peer reviewed.

Data availability statement Data are available on reasonable request. Data are available on request from the corresponding author T0; okuhara-ctr@umin.ac.jp.

Open access This is an open access article distributed in accordance with the Creative Commons Attribution Non Commercial (CC BY-NC 4.0) license, which permits others to distribute, remix, adapt, build upon this work non-commercially, and license their derivative works on different terms, provided the original work is properly cited, appropriate credit is given, any changes made indicated, and the use is non-commercial. See: http://creativecommons.org/licenses/by-nc/4.0/.

\section{ORCID iDs}

Tsuyoshi Okuhara http://orcid.org/0000-0002-6251-3587

Rie Yokota http://orcid.org/0000-0002-1973-2493

\section{REFERENCES}

1 Leone LA, Fleischhacker S, Anderson-Steeves B, et al. Healthy food retail during the COVID-19 pandemic: challenges and future directions. Int J Environ Res Public Health 2020;17:7397-14.

2 Mattioli AV, Sciomer S, Cocchi C, et al. Quarantine during COVID-19 outbreak: changes in diet and physical activity increase the risk of cardiovascular disease. Nutr Metab Cardiovasc Dis 2020;30:1409-17.

3 Scarmozzino F, Visioli F. Covid-19 and the subsequent lockdown modified dietary habits of almost half the population in an Italian sample. Foods 2020;9. doi:10.3390/foods9050675. [Epub ahead of print: 2505 2020].

4 Di Renzo L, Gualtieri P, Pivari F, et al. Eating habits and lifestyle changes during COVID-19 lockdown: an Italian survey. J Trans/ Med 2020;18:1-15.

5 Ministry of Health Labour and Welfare. 2019 National health and nutrition examination survey, 2019.

6 Yano Research Institute, Inc. 2021 market status and outlook of health food products, market analysis edition, Tokyo, 2020.

7 National Intsitute of Health. Dietary supplement health and education act of 1994. Available: https://ods.od.nih.gov/About/DSHEA_ Wording.aspx

8 Bureau S. Ministry of internal affairs and communications. Household Survey Report 2020.

9 Fortmann SP, Burda BU, Senger CA. Vitamin and mineral supplements in the primary prevention of cardiovascular disease and cancer: an updated systematic evidence review for the U.S. preventive services Task force. Forsch Komplementarmed 2014;21:55-8.

10 Supplements M. Editorial annals of internal edicine Enough Is Enough : Stop Wasting Money on Vitamin and Mineral Supplements. Ann Intern Med 2014:2-5.

11 Huang $\mathrm{H}-\mathrm{Y}$, Caballero B, Chang $\mathrm{S}$, et al. The efficacy and safety of multivitamin and mineral supplement use to prevent cancer and chronic disease in adults: a systematic review for a national Institutes of health state-of-the-science conference. Ann Intern Med 2006;145:372-85.

12 Miller ER, Pastor-Barriuso R, Dalal D, et al. Meta-analysis: highdosage vitamin $E$ supplementation may increase all-cause mortality. Ann Intern Med 2005;142:37-9.

13 Tsai H-H, Lin H-W, Simon Pickard A, et al. Evaluation of documented drug interactions and contraindications associated with herbs and dietary supplements: a systematic literature review. Int J Clin Pract 2012;66:1056-78.

14 Grubbs V, Plantinga LC, Tuot DS, et al. Americans' use of dietary supplements that are potentially harmful in CKD. Am J Kidney Dis 2013;61:739-47.

15 Bleys J, Navas-Acien A, Guallar E. Serum selenium levels and allcause, cancer, and cardiovascular mortality among US adults. Arch Intern Med 2008;168:404-10.

16 Amrein K, Quraishi SA, Litonjua AA, et al. Evidence for a U-shaped relationship between prehospital vitamin $D$ status and mortality: a cohort study. J Clin Endocrinol Metab 2014;99:1461-9.

17 Goyal A, Terry MB, Siegel AB. Serum antioxidant nutrients, vitamin $A$, and mortality in U.S. adults. Cancer Epidemiol Biomarkers Prev 2013;22:2202-11.

18 Fontanarosa PB, Rennie D, DeAngelis CD. The need for regulation of dietary supplements--lessons from ephedra. JAMA 2003;289:1568-70.

19 Drazen JM. Inappropriate advertising of dietary supplements. N Engl J Med 2003;348:777-8.

20 Avery RJ, Eisenberg MD, Cantor JH. An examination of structurefunction claims in dietary supplement advertising in the U.S.: 2003-2009. Prev Med 2017;97:86-92.

21 Zakaryan A, Martin IG. Regulation of herbal dietary supplements: is there a better way? Drug Inf J 2012;46:532-44.

22 Dickinson A, Blatman J, El-Dash N, et al. Consumer usage and reasons for using dietary supplements: report of a series of surveys. J Am Coll Nutr 2014;33:176-82.

23 Blendon RJ, DesRoches CM, Benson JM, et al. Americans' views on the use and regulation of dietary supplements. Arch Intern Med 2001;161:805-10.

24 Davis JJ. Ethics in advertising Decisionmaking: implications for reducing the incidence of deceptive advertising. J Consum Aff 1994;28:380-402. 
25 Adams KK, Baker WL, Sobieraj DM. Myth Busters: dietary supplements and COVID-19. Ann Pharmacother 2020;54:820-6.

26 Starr RR. Too little, too late: ineffective regulation of dietary supplements in the United States. Am J Public Health 2015;105:478-85.

27 The U.S. Food and Drug Administration. Fraudulent coronavirus disease 2019 (COVID-19) products. Available: https://www.fda.gov/ consumers/health-fraud-scams/fraudulent-coronavirus-disease2019-covid-19-products

28 Consumer Affairs Agency. Food products claiming to prevent new coronavirus (alert). Available: https://www.caa.go.jp/notice/entry/ 019773/

29 Health Canada. Health products that make false or misleading claims to prevent, treat or cure COVID-19 may put your health at risk. Available: https://healthycanadians.gc.ca/recall-alert-rappel-avis/hcsc/2020/72659a-eng.php

30 The Health Sciences Authority SG. Advisory on herbal products claiming to prevent or treat COVID-19 (coronavirus disease 2019). Available: https://www.hsa.gov.sg/consumer-safety/articles/details/ herbal-products-covid-19

31 The Therapeutic Goods Administration, Department of Health AG. Safety advisory - false and misleading claims relating to COVID-19. Available: https://www.tga.gov.au/alert/miracle-mineral-solution$\mathrm{mms}-0$

32 Japan Newspaper Publishers Association. Newspaper audience survey, 2019

33 Yomiuri Shimbun Advertising Bureau. Morning newspaper circulation and household penetration rates of the top 3 newspapers. Available: https://adv.yomiuri.co.jp/download/PDF/mediakit/general/ mediadata2020/prefectures.pdf

34 Consumer Affairs Agency. Points to be noted under the act against Unjustifiable premiums and misleading representations and the health promotion act in relation to health foods. Available: https:// www.caa.go.jp/policies/policy/representation/fair_labeling/pdf/ 160630premiums_8.pdf

35 Qato DM, Alexander GC, Conti RM. Use of prescription and over-thecounter medications and dietary supplements among older adults in the United States. JAMA - J Am Med Assoc 2008;300:2867-78.

36 Nishida S, Ono Y, Sekimizu K. Lactic acid bacteria activating innate immunity improve survival in bacterial infection model of silkworm. Drug Discov Ther 2016;10:49-56.

37 National Institute of Health Sciences. National Institute of health and nutrition in Japan, safety and efficacy information of health food. Available: https://hfnet.nibiohn.go.jp/

38 Lee $\mathrm{YH}$, Woo J-H, Choi SJ, et al. Effect of glucosamine or chondroitin sulfate on the osteoarthritis progression: a meta-analysis. Rheumatol Int 2010;30:357-63.

39 Eriksen P, Bartels EM, Altman RD, et al. Risk of bias and brand explain the observed inconsistency in trials on glucosamine for symptomatic relief of osteoarthritis: a meta-analysis of placebocontrolled trials. Arthritis Care Res 2014;66:1844-55.

40 Hochberg MC, Zhan M, Langenberg P. The rate of decline of joint space width in patients with osteoarthritis of the knee: a systematic review and meta-analysis of randomized placebo-controlled trials of chondroitin sulfate. Curr Med Res Opin 2008;24:3029-35.

41 Yang B, Lu P, Li M-X, et al. A meta-analysis of the effects of probiotics and synbiotics in children with acute diarrhea. Medicine 2019;98:e16618

42 Yurrita LC, Martín ISM, Ciudad-Cabañas MJ. Eficacia de la ingesta de inulina sobre los indicadores del estreñimiento crónico; un meta- análisis de ensayos clínicos aleatorizados controlados. Nutr Hosp 2014;30:244-52.

43 Yang J, Wang H-P, Zhou L, et al. Effect of dietary fiber on constipation: a meta analysis. World J Gastroenterol 2012;18:7378-83.

44 Wang Y, Li X, Ge T. Probiotics for prevention and treatment of respiratory tract infections in children: a systematic review and metaanalysis of randomized controlled trials. Med 2016;95.

45 Hao Q, Dong BR, Wu T. Probiotics for preventing acute upper respiratory tract infections. Cochrane Database Syst Rev 2015;2015:CD006895.

46 Akour A, Probiotics AA. Probiotics and COVID-19: is there any link? Lett Appl Microbiol 2020;71:229-34.

47 Pun JKH, Chan EA, Wang S, et al. Health professional-patient communication practices in East Asia: an integrative review of an emerging field of research and practice in Hong Kong, South Korea, Japan, Taiwan, and mainland China. Patient Educ Couns 2018;101:1193-206.

48 Ghoch ME, Valerio A. Let food be the medicine, but not for coronavirus: nutrition and food science, telling myths from facts. Jptcp 2020;27:e1-4.

49 Consumer Affairs Agency,. Request for improvement, and alert to general consumers, regarding labeling of products claiming prophylactic effects against novel coronavirus. Available: https:// www.caa.go.jp/notice/entry/020124/

50 Rodrigues MB, Matos JdeP, Horta PM. The COVID-19 pandemic and its implications for the food information environment in Brazil. Public Health Nutr 2021;24:321-6.

51 Consumer Affairs Agency. Consumer information on the novel corona virus. Available: https://www.caa.go.jp/policies/policy/consumer_ policy/information/notice/

52 Grantham JL, Verishagen CL, Whiting SJ, et al. Evaluation of a social media campaign in Saskatchewan to promote healthy eating during the COVID-19 pandemic: social media analysis and qualitative interview study. J Med Internet Res 2021;23:e27448.

53 Choi WJ, Kim HK. Health claims for food products advertised on Korean television and their regulation: a content analysis. $J$ Health Commun 2011;16:925-40.

54 Chiba T, Kobayashi E, Okura T, et al. An educational intervention improved knowledge of dietary supplements in college students. BMC Public Health 2020;20:1-12.

55 Sadeghirad B, Duhaney T, Motaghipisheh S, et al. Influence of unhealthy food and beverage marketing on children's dietary intake and preference: a systematic review and meta-analysis of randomized trials. Obes Rev 2016;17:945-59.

56 Vukmirovic M. The effects of food advertising on food-related behaviours and perceptions in adults: a review. Food Res Int 2015;75:13-19.

57 Boyland EJ, Whalen R. Food advertising to children and its effects on diet: review of recent prevalence and impact data. Pediatr Diabetes 2015;16:331-7.

58 Boyland EJ, Nolan S, Kelly B, et al. Advertising as a cue to consume: a systematic review and meta-analysis of the effects of acute exposure to unhealthy food and nonalcoholic beverage advertising on intake in children and adults. Am J Clin Nutr 2016;103:519-33.

59 Lapierre MA, Fleming-Milici F, Rozendaal E, et al. The effect of advertising on children and adolescents. Pediatrics 2017;140:S152-6. 